\title{
Positive energy imbalance and microflora overgrowth
}

\begin{abstract}
At meals, people aim to maintain their usual energy level and balance in blood and all tissues. People have subjectively formed this aim through months and years poorly consciously, i.e., outside any comparison with other people, other times or feeding conditions. The aim can be assessed as the weekly mean BG, $\pm 3.8 \mathrm{mg} / \mathrm{dL}$ (confidence interval) and may be evaluated in the overall stratification. After 2-48 hours of meal suspension, the aim spontaneously arises as Initial Hunger (IH). Recognition of three IH arousals per day produces an even energy balance and eliminates any conditioned intake at 20\% lower energy intake, 20\% lower Mean BG, 20\% lower RMR and 30\% lower insulin resistance than automatic, conditioned feeding.
\end{abstract}

Volume 7 Issue 2 - 2017

Mario Ciampolini
Preventive Gastroenterology, Department of Pediatrics,
University of Florence, Italy

Correspondence: Mario Ciampolini, Department of Pediatrics, University of Florence, Florence, Italy, Emailmlciampolini@fastwebnet.it

Received: September 14, 2017| Published: September 19, 2017

\section{Immunogenic bacteria}

Minimal bacteria growth on small intestinal mucosa is associated with prompt absorption of food, as happens during insulin sensitivity. ${ }^{1-68}$ Any meal by meal excess intake over expenditure (insulin resistance) fosters microflora growth and reversible immune deficiency (RID: subclinical inflammation, overall inflammatory state, or pro-inflammatory state)..$^{1,2,66-71}$ Overweight is the cumulative result of meal by meal positive balance for a period of time. Weight increase and fattening produce an increase in insulin resistance and RID. A weight stable is poorly effective on subclinical inflammation, and weight decreases diminish the overall inflammation. In the small intestine, unabsorbed food becomes harmful to mucosa and all the body for the existence of bacteria in the intestinal lumen and the possibility of an active proliferation inside the lumen until food is available. ${ }^{68}$. On the contrary, rearing experimental animals without bacteria reduced to $10 \%$ cellular infiltration and immunoglobulin production in small intestine mucosa. ${ }^{70}$ Tropical enteropathy exhibits a denser infiltrate than normal mucosa in dependence on absorption slowdown in a warm and humid climate.

The conception of intestinal saprophytes was rather naïve. Bacteria grow in the colon and everywhere in dependence of water and available nutrients and temperature. Water is freely available on mucosal surfaces, and nutrients (carbohydrates, proteins) depend on eating and more precisely on current energy balance. We compared the xylose absorption rate in two groups of experimental animals, one at the environmental temperature of $30^{\circ} \mathrm{C}$ and the other at $6{ }^{\circ} \mathrm{C}$ environmental temperature..$^{59}$ At high environmental temperature, the absorption rate halved in comparison to animals kept at low temperature. We obtained similar results in humans. ${ }^{60}$ A slowdown of metabolic and absorption rates explain unexpected microflora growth. ${ }^{59-64}$ Bacteria in the colon double every day, very slowly in comparison with growth in the small intestine, where bacteria can double every 15 minutes. ${ }^{68}$ Bacteria obtain little energy from non-absorbable, indigestible fibers in absence of oxygen. All meat, bread and every good meal component do not arrive to the colon. These highly energetic foods would promote an explosive growth. The rumen is similar to the human colon in hosting bacteria in an ambient that has poor nutrients and is absolutely devoid of oxygen. Energy rich nutrients let develop one-two liters of carbodioxid per minute in the rumen. The small intestine is also anaerobic, and oxygen absence increases toward the end of the intestine. $60 \%$ of bacteria do not stimulate any immune response. ${ }^{69} 10 \%-15 \%$ evoke a response by IgG lymphocytes and neutrophils that are destructive on invading bacteria, mucosa and overall in the body by subclinical inflammation. Minimal bacteria growth requires minimal persistence of nutrients in the small intestine lumen like on teeth. This depends on intake amount and rhythm. Amounts and intervals can be externally decided by doctors, who apply standard international averages from healthy people. Any decision about eating start, the amount and any stop may better be taken by the subject's estimation of personal cues on the personal energy balance. The suspension of food administration to a healthy baby with functional bowel disorders provoked crying for hunger (Initial Hunger, $\mathrm{IH}$ ) within 48 hours of time..$^{39,40}$ This cue was subjective although being more certain than any laboratory measure. As pediatricians, we provisionally assumed that crying for hunger corresponded to initial emptiness of stomach and small intestine and to the time of most active absorption. ${ }^{39,40}$ The administration amount might correspond to expenditure in the interval between subsequent similar meal demands. This correspondence is exact in the long (monthly) period. Insulin resistance may sometimes arise independently from eating, like during psychological stress and fever. A transient break in eating is useful in these events that are associated with insulin resistance. Although the energy expenditure increases and body energy balance is negative during fever, preprandial BG remains high, and the balance in blood is positive for energy influx from fat stores. ${ }^{71-73}$ We consider this divergence as acceptable and normal. Hormones that allow the body to meet stress such as cortisol, cortisol releasing factor, and serotonin together raise blood glucose concentration, activate mast cells, monocytes, and macrophages, increase intestinal permeability, and contribute to subclinical inflammation-essentially the same effects as eating in the absence of IH. Suspension of meals for one three days is accepted. Yet the balance problem becomes difficult when a stressful condition persists for weeks. ${ }^{1,2}$

\section{Positive energy imbalance and microflora overgrowth}

The maintenance of inflammation is much more pronounced in the mucosa of the small intestine than in that of the colon. The more intense conflict against the luminal content may depend on the surface area that has been estimated as high as 10000 square meters in the 
small intestine. The colon surface is devoid of villi and microvilli and may be about one square meter. One-two percent of big molecules in the lumen cross the small intestine epithelium, and exercises an immune stimulation inside the mucosa. For unknown reasons, bacteria exert immune stimulation more than food..$^{70} \mathrm{We}$ insist that bacteria multiply in dependence on nutrients availability, mainly on energy and iron. The host gives ammonium for bacterial proteins. Minimal bacteria growth on the mucosa is a necessary step to achieve health, like on the periodontal mucosa. During positive energy imbalance, the small intestinal absorption slows down; intestinal microflora grows and produces an increase in the inflammatory infiltrate in the small intestine and reversible functional derangements. ${ }^{65-70}$ In experimental animals, we have described an increase of inflammatory cells in the mucosa after administration of broth culture containing Escherichia coli. $^{75-77}$ This bacterium was not a pathogen, but elicited an inflammatory response, as an immunogenic component of intestinal microflora. We showed an increase in bacteria number in biopsies of children during absorption and a decrease in bacteria number after the last meal..$^{70-72}$ Subjects with irritable bowel syndrome (in infancy, chronic nonspecific diarrhea) actually show an increase in mucosal inflammatory cells. ${ }^{78-84}$ Suppression and a decrease in intake cured these diarrheic toddlers by subtracting nutrients to mucosal microflora. Decrease in insulin resistance and in overall inflammation might have influenced the recovery.

\section{Immune involvement}

In our laboratory hypothesis, each meal carries on a battle. Every meal renews or reignites the never ending conflict between bacteria growing on mucosa and immune reaction. Sometimes the conflict is acute, symptomatic; more often damages all body although progressing without any awareness (overall subclinical inflammation). Bacteria double every 10-20 minutes in the small intestinal nutrients. ${ }^{60-64,78-96}$. The mucosa of the small intestine hosts half the body production of immune cells and sustains a permanent moderate local inflammation, consisting of IgA and phagocytic responses, "tolerant" inflammation. ${ }^{97-99}$ About one hundred commensal bacteria are immunogenic in the human intestine.$^{69} \mathrm{An}$ increase in this bacterial growth to about one billion per gram of mucosa provokes increase in production of lymphocyte and of $\operatorname{IgG}$ antibodies and reactions with mucosal damages. ${ }^{75-89}$ The local inflammation discharges antigens and activated monocytes in circulation, producing a subclinical inflammation throughout the body. ${ }^{1-25}$ This inflammation has received many names: overall inflammation, proinflammatory state and Reversible Immune Deficiency (RID). ${ }^{2}$ We preferred these two last names to emphasize the detrimental, immune involvement of the entire body from meal energy intakes that are unbalanced by correspondent high energy expenditure. This immune involvement increases and prolongs all localized inflammations and worsens general diseases. ${ }^{1-25}$ The suppression of the immune stimulation of intestinal mucosa was the strategy for a new life, for recovery from infection, from immune illnesses and from malnutrition as well as from obesity and to prevent risks and deterioration for everybody. Short absorption times (twothree hours) alternated with periods of emptiness may achieve this goal.

\section{Overall subclinical inflammation}

"Insulin resistance" is associated with a "pro-inflammatory state" or "subclinical inflammation", and the association is supported by a huge amount of research. ${ }^{1-25,97-99}$ The findings of this association represent a high achievement in understanding human nutrition and health. The general acceptance of this association took unfortunately 80 years. ${ }^{22-25}$. Persistent unbalanced energy intake and/or psychophysical stresses modify the activity of monocytes, macrophages and mast cells, and together alter the neuro-endocrine system. ${ }^{1-25}$. These disorders increase intestinal permeability. ${ }^{95}$ Bacterial biofilms may develop inside the alimentary canal and produce endotoxins that invade blood and all tissues. Immunogenic bacteria induce a huge biological pressure on human immune system and deep functional alterations. The invasion of body tissues by bacterial products and endotoxins sustains subclinical inflammation and causes the slow progression of many chronic diseases, like asthma and rheumatoid arthritis. Thus, body tissues develop a pro-inflammatory state (subclinical inflammation, a synonym) that is sterile, ineffective and dangerous for body tissues in the intestine and elsewhere.

\section{Health as minimal immune stimulation}

The antibiotic treatment of pneumonia and consequent recovery shows the potential harm of some of the 30-100 bacterial species that may spread from the alimentary canal and superimpose on a viral infection. An abundance of nutrients, slowdown of absorption and microflora overgrowth begin the causal chain between intake and subclinical inflammation, functional disorders, deterioration and risks. The nutrient abundance just coincides with insulin resistance and progression in fattening, two events that are associated even when appear alone. Also the absorption slowdown coincides with the condition of insulin resistance, although the evidence is poorer. In animal experiments, insulin infusion into portal vein increased intestinal absorption rate. ${ }^{80}$ After a similar intake, we found a decrease in the absorption rate in a warm environment in comparison with a cold environment in both animal and human experiments..$^{59,60,72}$ The cold environment is associated with higher energy expenditure than the warm one. ${ }^{6}$. The increase in energy expenditure decreases insulin resistance. ${ }^{62-64}$ We may mention also the absorption slowdown that is well known and accepted during infection and inflammation. ${ }^{71}$ We conclude that healthy nutrition, at least provisionally, coincides with insulin sensitivity, whereas slow absorption and subclinical inflammation (Reversible Immune Deficiency, RID) develop during an increase in insulin resistance. In our studies, disordered bacteria growth on intestinal mucosa and overall subclinical inflammation are due to a unifying pathogenic factor, insulin resistance.

\section{Acknowledgments}

None.

\section{Conflicts of interest}

The authors declare no conflicts of interest.

\section{References}

1. Ciampolini M. Meal by meal dynamic balance of energy in blood. Research Signpost, Kerala, India. 2013.

2. Ciampolini M. Interruption of automatic feeding, of fattening and associated immune deficiency. Recent Res Devel Nutrition. 2013;9:131.

3. Bastard JP, Maachi M, Lagathu C, et al. Recent advances in the relationship between obesity, inflammation, and insulin resistance. Eur Cytokine Netw. 2006;17(1):4-12.

4. Gustavsson CG, Agardh CD. Markers of inflammation in patients with coronary artery disease are also associated with glycosylated hemoglobin A1c within the normal range. Eur Heart J. 2004;25(23):2120-2124.

5. Vozarova B, Weyer C, Lindsay RS, et al. High white blood cell count is associated with a worsening of insulin sensitivity and predicts the development of type 2 diabetes. Diabetes. 2002;51(2):455-461. 
6. Bloomgarden ZT. Insulin resistance:causes and consequences. Int Rev Neurobiol. 2005;65:1-24.

7. Biddinger SB, Kahn CR. From mice to men:insights into the insulin resistance syndromes. Annu Rev Physiol. 2006;68:123-158.

8. Dinan TG, Quigley EM, Ahmed SM, et al. Hypothalamic-pituitary-gut axis dysregulation in irritable bowel syndrome:plasma cytokines as a potential biomarker? Gastroenterology. 2006;130:304-311.

9. Ohman L, Simrén M. Pathogenesis of IBS:role of inflammation, immunity and neuroimmune interactions. Nat Rev Gastroenterol Hepatol. 2010;7(3):163-173.

10. Spiller R, Garsed K. Postinfectious irritable bowel syndrome. 2010. Gastroenterology. 2009;136(6):1979-1988.

11. Li X, Chen H, Lu H, et al. The study on the role of inflammatory cells and mediators in post-infectious functional dyspepsia. 2010. Scand $J$ Gastroenterol. 2010;45(5):573-581.

12. Wallon C, Söderholm JD. Corticotropin-releasing hormone and mast cells in the regulation of mucosal barrier function in the human colon. Ann N Y Acad Sci. 2009;1165:206-210.

13. Larauche $\mathrm{M}$, Kiank $\mathrm{C}$, Tache $\mathrm{Y}$. Corticotropin releasing factor signaling in colon and ileum:regulation by stress and pathophysiological implications. J Physiol Pharmacol. 2009;60(Suppl 7):33-46.

14. Reaven GM. The metabolic syndrome:is this diagnosis necessary? Am J Clin Nutr. 2006;83(6):1237-1247.

15. Smith CW. Diet and leukocytes. Am J Clin Nutr. 2007;86 (5):1257-1258.

16. Bigorgne AE, Bouchet-Delbos L, Naveau S, et al. Obesity-Induced Lymphocyte Hyperresponsiveness to Chemokines:A New Mechanism of Fatty Liver Inflammation in Obese Mice. Gastroenterology. 2008;134(5):1459-1469.

17. Cani PD, Amar J, Iglesias MA, et al. Metabolic endotoxemia initiates Obesity and Insulin Resistance. Diabetes. 2007;56(7):1761- 1772.

18. Chichlowski M, Westwood GS, Abraham SN, et al. Role of mast cells in inflammatory bowel disease and inflammation-associated colorectal neoplasia in IL-10-deficient mice. 2010, PLoS One. 2010;5(8):e12220.

19. Kinlen LJ. Non-Hodkin's lymphoma after immunosuppressive therapy Gut. 2000;47:462-463.

20. Chow WH, Gridley G, Fraumeni JF Jr, et al. Obesity, Hypertension, and the risk of kidney cancer in men. $N$ Engl J Med. 2000;343(18):13051311

21. Lichtenstein P, Holm NV, Verkasalo PK, et al. Environmental and heritable factors in the causation of cancer. Analyses of cohorts of twins from Sweden, Denmark, and Finland. N Engl J Med. 2000;343(2):7885

22. Kylin E. Studien ueber Hypertonie-Hyperglykamie-Hyperurikamie syndrome. Zentralblatt fur innere Medizin 1923;44.

23. Randle PJ, Garland PB, Hales CN, et al. The glucose-fatty acid cycle:its role in insulin sensityvity and the metabolic disturbances of diabetes mellitus. Lancet. 1963;1(7285):785-789.

24. Reaven GM. Banting Lecture. Role of insulin resistance in human disease. Diabetes. 1988;37(12):1595-1607.

25. Festa A, D’Agostino R, Howard G, et al. Chronic subclinical inflammation as part of the insulin resistance syndrome:the Insulin Resistance Atherosclerosis Study (IRAS). Circulation. 2000;102(1):4247

26. Hossain P, Kawar B, El Nahas M. Obesity and diabetes in the devel $\neg$ oping world - a growing challenge. N Engl J Med. 2007;356(3):213-215.

27. Mozaffarian D, Hao T, Rimm EB, et al. Changes in diet and lifestyle and long-term weight gain in women and men. $N$ Engl $J$ Med. 2011;364(25):2392-2404.
28. Polivy J, Herman CP. An evolutionary perspective on dieting. Appetite. 2006;47(1):30-35

29. Sumithran P, Prendergast LA, Delbridge E, et al. Long-term persis $\neg$ tence of hormonal adaptations to weight loss. $N$ Engl J Med. 2011;365(17):1597-1604.

30. Lang L. Insulin-producing beta-cells arise via self-duplication Gastroenterology. 2044;127(5):1288.

31. Polonsky KS, Sturis J, Bell GI. Non-Insulin-Dependent Diabetes Mellitus A Genetically Programmed Failure of the Beta Cell to Compensate for Insulin Resistance. N Engl J Med. 1996;334:777-783.

32. Dulloo AG. Thrifty energy metabolism in catch-up growth trajectories to insulin and leptin resistance. Best Pract Res Clin Endocrinol Metab. 2008;22(1):155-171.

33. Verdich C, Toubro S, Buemann B, et al. The role of postprandial releases of insulin and incretin hormones in meal induced satiety. Effect of obesity and weight reduction. Int J Obes Relat Metab Disord. 2001;25(8):1206-1214.

34. Wiesli P, Schäffler E, Seifert B, et al. Islet secretory capacity determines glucose homoeostasis in the face of insulin resistance. Swiss Med Wkly. 2004;134(37-38):559-564.

35. Kraegen E, Cooney G, Ye JM, et al. Peroxisome proliferator activated receptors, fatty acids and muscle insulin resistance. $J R$ Soc Med. 2002;95(Suppl 42):14-22.

36. Corcoran MP, Lamon-Fava S, Fielding RA. Skeletal muscle lipid deposition and insulin resistance:effect of dietary fatty acids and exercise. Am J Clin Nutr. 2007;85(3):662-677.

37. Westerterp KR. Diet induced thermogenesis. Nutr Metab (Lond). (2004;1(1):5.

38. Jequier E. Thermogenic responses induced by nutrients in man: their importance in Energy balance regulation. Mauron (Ed). Nestle Nutrition Research Symposium, Vevey, Switzerland. 1983. pp. 26-44.

39. Ciampolini M. Requested meals versus scheduled meals. I J Gen Med. 2012;5:1-9.

40. Ciampolini M, Brenna JT, Giannellini V, et al. Interruption of scheduled, automatic feeding and reduction of excess energy intake in toddlers. Intern J Gen Med. 2013;6:39-47.

41. Ciampolini M, Lovell-Smith D, Sifone M. Sustained self-regulation of energy intake. Loss of weight in overweight subjects. Maintenance of weight in normal-weight subjects. Nutr Metab (Lond). 2010;7:1-4.

42. Ciampolini M, Sifone M. Differences in maintenance of mean Blood glucose (BG) and their association with response to "Recognizing Hunger". IJ Gen Med. 2011;4:403-412.

43. Henry RR, Wallace P, Olefsky JM. Effects of weight loss on mechanisms of hyperglycemia in obese non-insulin-dependent diabetes mellitus. Diabetes. 1986;35(9):990-998.

44. Olefsky JM, Reaven GM, Farquhar JW. Effects of weight reduction on obesity:Studies of carbohydrate and lipid metabolism in normal and hyperlipoproteinemic subjects. J Clin Invest. 1974;53(1):64-76.

45. Garvey WT, Huecksteadt TP, Matthaei S, et al. Role of glucose transporters in the cellular insulin resistance of type II non-insulindependent diabetes mellitus. J Clin Invest. 1988;81(5):1528-1536.

46. Kolterman OG, Gray RS, Griffin J, et al. Receptor and post receptor defects contribute to the insulin resistance in Noninsulin-Dependent diabetes mellitus. J Clin Invest. 1981;68(4):957-969.

47. Akazawa H, Kawasaki E, Sun F, et al. Efficacy of Troglitazone on Body Fat Distribution in Type 2 Diabetes. Diabetes Care. 2000;23(8):10671071.

48. Vague J. Obesities. 1st edn, London: John Libbey and Company Ltd, UK, 1991. p. 20. 
49. Hirsch J. Adipose cellularity in relation to human obesity. In: Stollerman $\mathrm{GH}$, editor. Advances in Internal Medicine, Year Book Medical Publishers, Chicago, USA, 1971. pp. 289-300.

50. Groop LC, Tuomi T. Non-insulin-dependent diabetes mellitus-A collision between thrifty genes and an affluent society. Ann Med. 1997;29(1):37-53.

51. Dorfler H, Rauh G, Basserman R. Lipoatrophic diabetes. Clin Investig. 1993;71(4):264-269.

52. Ciampolini M, Conti A, Bernardini S, et al. Internal stimuli controlled lower calorie intake:effects after eight months in toddler's diarrhoea. Ital J Gastroenterology. 1987;19:201-204.

53. Ciampolini M, Vicarelli D, Seminara S. Normal energy intake range in children with chronic non-specific diarrhea:Association of relapses with the higher level. J Pediatr Gastroenterol Nutr. 1990;11(3):342-350.

54. Matsuda M, DeFronzo RA. Insulin sensitivity indices obtained from oral glucose tolerance testing:comparison with the euglycemic insulin clamp. Diabetes Care. 1999;22(9):1462-1470.

55. Mattheus DR, Hosker JP, Rudenski AS, et al. Homeostasis model assessment:insulin resistance and beta cell function from fasting plasma glucose and insulin concentrations in man. Diabetologia. 1985;28(7):412-419.

56. Ciampolini M, Bini S, Giommi A, et al. Same growth and different energy intake over four years in children suffering from chronic nonspecific diarrhea. Int J Obes Relat Metab Disord. 1994;18(1):17-23.

57. Ciampolini M, Borselli L, Giannellini V. Attention to metabolic hunger and its effects on Helicobacter pylori infection. Physiol Behav. 2000;70(3-4):287-296.

58. Frisancho AR. New norms of upper limb fat and muscle areas for assessment of nutritional status. Am J Clin Nutr. 1981;34(11):25402545 .

59. Ciampolini M. Influence of environmental temperature on intestinal absorption xylose in rats in vivo. IRCS. 1974;2:1545.

60. Ciampolini M. Influence of environmental temperature on xilose absorption in man. IRCS Med Sci. 1976);4:208.

61. Hammel HT. Terrestrial animals in cold:recent studies of primitive man. In: Dill DB, editor. Handbook of Physiology, sect 4, adaptation to the environment. Amer Physiol Soc, Washington DC, USA, 1964. pp. 413 -434 .

62. Schmidt MI, Matos MC, Branchtein L, et al. Variation in glucose tolerance with ambient temperature. Lancet. 1994;344(8929):1054 1055 .

63. Elliott SS, Keim NL, Stern JS, et al. Fructose, weight gain, and the insulin resistance syndrome. Am J Clin Nutr. 2002;76(5):911-922.

64. Barnett JL, Owyang C. Serum glucose concentration as a modulator of interdigestive gastric motility. Gastroenterology. 1988;94(3):739-744.

65. Molnar D, Schutz Y. Fat oxidation in nonobese and obese adolescents:Effect of body composition and pubertal development. $J$ Pediatr. 1998;132(1):98-104.

66. Ciampolini M. Interruption of automatic feeding, of fattening and associated immune deficiency. Recent Res Devel Nutrition. 2013; 9(2013):1-31.

67. Waterland RA, Garza C. Potential mechanisms of metabolic imprinting that lead to chronic disease. Am J Clin Nutr. 1999;69(2):179-197.

68. Ciampolini M, Bini S, Orsi A. Microflora persistence on duodenojejunal flat or normal mucosa in time after a meal in children. Physiol Behav. 1996;60(6):1551-1556.

69. vander Waaij LA, Limburg PC, Mesander G, et al. In vivo IgA coating of anaerobic bacteria in human faeces. Gut. 1996;38(3):348-354.
70. Abrams GD. Microbial effects on mucosal structure and function. Am J Clin Nutr. 1977;30(11):1880-1886.

71. Beisel WR. Herman Award lecture, 1995:Infection-induced malnutrition-from cholera to cytokines. Am J Clin Nutr. 1995;62(4):813819

72. Stuempel F, Kucera T, Gardemann A, et al. Acute increase by portal insulin in intestinal glucose absorption via hepatoenteral nerves in the rat. Gastroenterology. 1996;110(6):1863-1869.

73. Robbins TW, Fray PJ. Stress induced eating: fact, fiction or misunderstanding? Appetite. 1980;1(2):103-133.

74. Söderholm JD, Yang PC, Ceponis P, et al. Chronic stress induces mast cell-dependent bacterial adherence and initiates mucosal inflammation in rat intestine. Gastroenterology. 2002;123(4):1099-1108.

75. Ciampolini M. On the action of germs in the small intestine. I. Intestinal germs as factors of malabsorption. Riv Clin Ped. 1969;82(2):64-72.

76. Ciampolini M, Becciolini PA, Marianelli. On the effect of germs in the small intestine. In vitro effect on saccharase and leucine aminopeptidase. Riv Clin Ped. 1969;82(3):99-104.

77. Ciampolini M, Marianelli L. On the action of germs in the small intestine. II. E. coli in the suckling rat. Microbiologic, histologic and biochemical study. Riv Clin Ped. 1969;82(2):78-84.

78. Mata LJ, Jimenez F, Cordon M, Rosales R, et al. Gastrointestinal flora of children with protein-calorie malnutrition. Am J Clin Nutr. 1972;25(10):1118-1126.

79. Mc Nabb PC, Tomasi TB. Host defense mechanisms at mucosal surfaces. Ann Rev Microbiol. 1981;35:477-496.

80. Mortimer DC, Reed PI, Vidinli M, et al. The role of the upper gastrointestinal flora in the malabsorption syndrome. Cana. Med Assoc J. 1964;90:559-564.

81. Nelson DP, Mata LJ. Bacterial flora associated with the human gastrointestinal mucosa. Gastroenterology. 1970;58(1):56-61.

82. Omoike IV, Abiodun PO. Upper small intestinal microflora in diarrhea and malnutrition in nigerian children. $J$ Pediatr Gastroenterol Nutr. 1989;9(3):314-321.

83. Peach S, Lock MR, Katz D, et al. Mucosal associated bacterial flora of the intestine in patients with Crohn's disease and in control. Gut. 1978;19(11):1034-1042.

84. Penny ME, Da Silva DGH, Mc Neish AS. Bacterial contamination of the small intestine with enteropathogenic Escherichia coli and other enteric infections, a factor in the etiology of persistent diarrhoea. $\mathrm{Br} \mathrm{Med} J$. 1986;292:1223-1226.

85. Corazza GR, Menozzi MG, Strocchi A, et al. The diagnosis of small bowel bacterial overgrowth. Gastroenterology. 1990;98(2):302-309.

86. Cooke WT, Holmes GKT. Bacterial flora of the upper small intestine. In:Cooke WT \& Holmes GKT (Eds.), Coeliac disease. Churchill Livingstone, London, UK, 1984. p. 68-80.

87. Cuvelier C, Mielants H, De Vos M, et al. Major histocompatibility complex class II antigen (HLA-DR) expression by ileal cells in patients with seronegative spondylarthropathy. Gut. 1990;31(5):545-549.

88. Daifuku R, Stamm WE. Bacterial adherence to bladder uroepi-thelial cells in catheter-associated urinary tract infection. $N$ Engl $\mathrm{J} \mathrm{Med}$. 1986;314(19):1208-1213.

89. Davidson GP, Robb TA, Kirubakaran CP. Bacterial contamination of the small intestine as an important cause of chronic diarrhea and abdominal pain:diagnosis by breath hydrogen test. Pediatrics. 1984;74(2):229-235.

90. Dixon JMS. The fate of bacteria in the small intestine. J Path Bact. 1960;79:131-140. 
91. Drasar BS, Shiner M, MC Leod GM. Studies on the intestinal $1 \mathrm{f}$ ora. I. The bacterial flora of the gastrointestinal tract in healthy and achlorhydric persons. Gastroenterology. 1969;56:71-79.

92. Drasar BS, Shiner M. Studies on the intestinal flora. Part II Bacterial flora of the small intestine in patients with gastrointestinal disorders. Gut. 1969;10(10):812-819.

93. Evans N, Brueton M, Turner PJ, et al. Bacterial culture of jejunal mucosa in childhood coeliac disease. Lancet. 1975;2(7923):35-36.

94. Fagundes Neto U, Toccalino H, Dujovney F. Stool bacterial aerobic overgrowth in the small intestine of children with acute diarrhoea. Acto Paediatr Scand. 1976;65(5):609-615.

95. Kinugasa T, Sakaguchi T, Gu X, et al. Claudins regulate the intestinal barrier in response to immune mediators. Gastroenterology. 2000;118(6):1001-1011
96. Perez PF, Doré J, Leclerc M, et al. Bacterial Imprinting of the Neonatal Immune System: Lessons From Maternal Cells? Pediatrics. 2007;119(3):e724-e732.61.

97. Rothkoetter HJ, Kirchhoff T, Pabst R. Lymphoid and non-lymphoid cells in the epithelium and lamina propria of intestinal mucosa of pigs. Gut. 1994;35(11):1582-1589.

98. Brandtzaeg P, Baklien K. Immunoglobulin-producing cells in the intestine in health and disease. Clinics in Gastroenterology. 1976;5:251269

99. Brandtzaeg P, Halstensen TS, Kett K, et al. Immunobiology and immunopathology of human gut mucosa: humoral immunity and intreaepithelial lymphocytes. Gastroenterology. 1989;97(6):1562-1584. 